\title{
A Survey Study on Medicinal Plants and Mushrooms Use in Treatment of Cancer by Patients at The Istanbul University Institute of Oncology \\ İstanbul Üniversitesi Onkoloji Enstitüsü'nde Hastalar Tarafindan Kanser Tedavisinde Kullanılan Tıbbi Bitkiler ve Mantarlar Üzerine Bir Anket Çalışması
}

\author{
Hüseyin Onur Tuncay ${ }^{1}$ (i), Miraç Ekici ${ }^{1}$ (i), Büşra Teke ${ }^{2}$ (i), Emine Akalın Uruşak ${ }^{1}$ (i)
}

Istanbul University, Faculty of Pharmacy, Department of Pharmaceutical Botany, İstanbul, Turkey

\footnotetext{
2 Hacettepe University, Faculty of Pharmacy, Department of Pharmaceutical Technology, Ankara, Turkey
}

ORCID: H.O.T. 0000-0003-1566-4806; M.E. 0000-0002-2793-3084; B.T. 0000-0001-5813-8625; E.K.U. 0000-0002-0307-2128

Corresponding author/Sorumlu yazar: Hüseyin Onur Tuncay, Istanbul University, Faculty of Pharmacy, Department of Pharmaceutical Botany, İstanbul, Turkey

E-mail: mugeay@istanbul.edu.tr

Submitted/Bașvuru: 04.06.2020 Accepted/Kabul: 24.06 .2020

Citation/Atıf: Tuncay HO, Ekici M, Teke B, Akalin Urusak E. A Survey Study on Medicinal Plants and Mushrooms Use in Treatment of Cancer by Patients at The Istanbul University Institute of Oncology. Sağlık Bilimlerinde İleri Araştırmalar Dergisi 2020; 3(2): 51-60.

https://doi.org/10.26650/JARHS2020-748136

\section{ABSTRACT}

Objective: Medicinal herbs are commonly used as complementary or prophylaxis in common illness, as well as in diseases such as cancer, where the disease is severe. In order to determine the use of plants and mushrooms among cancer patients, a survey was conducted with 100 cancer patients who are receiving treatment at polyclinics at the Istanbul University Institute of Oncology.

Material and Methods: The questionnaires were conducted face to face with the patients and the results were evaluated in computer.

Results: According to the survey results, only 24 of 100 patients were found to use the plants and mushrooms for treatment, to reduce the side effects of the treatment or to feel better. As a result, it was determined that a total of 17 different plants and 1 mushroom were used. The mechanism of action, side effects, and warnings of these plants and mushrooms on cancer treatment have been investigated. With this study, it was determined how the patients obtained the plants and mushrooms, how the age, gender or socioeconomic status affect the plants and mushrooms used and what kind of feedback the patients give about their experience.

Conclusion: The fact that the plants and mushrooms are not supplied by pharmacies, the application of herbal treatments with the advice of people under the title "expert" and "reliable" cause many problems. The survey study yielded promising results about the use of plants and mushrooms by cancer patients in Turkey. Similar studies are expected to be conducted in more clinics.

Keywords: Survey, cancer, Istanbul University Institute of Oncology, medicinal plants, medicinal mushrooms

\section{öz}

Amaç: Bitkiler ve mantarlar, tamamlayıcı veya koruyucu olarakbasit hastalıklarda kullanıldığı gibi kanser gibi tedavisi ağır olan hastalıklarda da yaygın olarak kullanılmaktadır. Kanser hastaları arasında bitki ve mantar kullanımını belirlemek amacıyla İstanbul Üniversitesi Onkoloji Enstitüsü’nde polikliniklerde tedavi gören 100 kanser hastası ile bir anket çalıșması yapılmıştır.

Gereç ve Yöntem: Anketler hastalarla yüz yüze gerçekleştirilmiş ve sonuçlar bilgisayar ortamında değerlendirilmiştir.

Bulgular: Anket sonuçlarına göre, 100 hastanın sadece 24'ünün bitki ve mantarları tedavi edici, tedavinin yan etkilerini azaltıcı veya daha iyi hissetmek için kullandığı saptanmıștır. Anket sonucunda toplam 17 farklı bitki ve 1 mantarın kullanıldığı tespit edilmiștir. Bu bitki ve mantarların kanser tedavisi üzerindeki etki mekanizması, yan etkileri ve uyarıları araştırılmıştır. Bu çalışma ile kanser hastalarının bitki ve mantarları nasıl temin ettikleri, yaş, cinsiyet veya sosyoekonomik durumun bitki ve mantar kullanımını nasıl etkilediği, kullanılan bitki veya mantardan yarar veya zarar nedeniyle ne tür geri bildirimler alındığı belirlenmiştir. Sonuç: Bitkilerin ve mantarların eczanelerden tedarik edilmemesi, "uzman" ve "güvenilir" başlığı altındaki kişilerin tavsiyesi ile bitkisel tedavilerin uygulanması birçok soruna neden olmaktadır. Yapılan anket çalışması, Türkiye'de kanser hastalarının bitki ve mantar kullanımına ilișkin fikir oluşturması açısından umut verici sonuçlar vermiștir. Gelecekte yapılacak benzer çalışmalar ile kanser tedavisi almakta olan hastaların bitki ve mantar kullanımlarının öğrenilmesi ve hastanın bir bütün olarak ele alınarak bu konuda eğitim almıș uzmanların tavsiye vermeleri ümit edilmektedir.

Anahtar Kelimeler: Anket, kanser, İstanbul Üniversitesi Onkoloji Enstitüsü, tıbbi bitki, tıbbi mantar 


\section{INTRODUCTION}

Plants have been used by humans since ancient times. Neanderthal remains dating back to 60 thousand years ago, have been identified between 1957 and 1961 in Şanidar Cave in Northern Iraq. Next to this human residue that is thought to be a shaman, plants such as hibiscus, cornflower, purple hyacinth, groundsel, yarrow, and ephedra have been founded. This discovery is considered to be the first data for the beginning of the relationship between the human and plants (1). Some relics which belong to Mesopotamian, Hittite, Greek, Egyptian, Roman, Byzantine, Arabic; Ottoman and Seljuk Civilizations demonstrate that plants are used for treatments by humans. The most important of these pieces is Materia Medica, written by the Greek physician and pharmacologist Dioscorides who lived in the 1st century AD. Materia Medica includes more than 660 herbal substances. Dioscorides, due to this contribution, is considered the founder of modern plant science (2).

Treatments and methods that are used in addition to the standard treatments or instead of standard treatments are called Complementary \& Alternative Medicine (CAM). When applied together with today's Western Medicine, these methods are used to improve the condition of the patient without reducing the effect of the current treatment. These treatments are expected to support the current treatment and to have a more rapid recovery when applied to the patient (3).

Phytotherapy is a field of medicine that aims to treat the disease with plants or maintain health. Phytotherapy is a science-based medical practice and therefore differs from traditional approaches based on traditional knowledge. It is one of the traditional and complementary treatment methods and contains the most satisfying data in terms of scientific evidence. Although it is sometimes referred to as Complementary and Alternative Medicine (CAM), phytotherapy, as a branch of science, has never emerged as an alternative to modern medicine $(4,5)$.

In a study, 300 participants who were randomly chosen at the city center of Eskişehir filled out the questionnaires (6). Results showed that $60 \%$ of the respondents use various types of CAM. $21.3 \%$ of participants use only one CAM method whereas $38.7 \%$ of them use two or more CAM methods. The main methods are using plants, megavitamins, diet, fish and animals, practising acupuncture, massage, physical therapy, bonesetting, prayer, yoga, reiki, and meditation. Considering the general distribution of CAM methods, plants are the first with 30\% (6).

In studies conducted in Turkey on the use of CAM in cancer patients, data has been collected from 5,252 cancer patients (5,069 adults and 183 pediatric) so far. The literature review about the CAM usage of cancer patients in Turkey shows that the frequency of CAM usage varies between $22.1 \%$ and $84.1 \%$. The most used type of CAM was herbal preparations (mostly "Urtica dioica"). Other methods are praying, doing religious practices, using vitamins, and special diets. Most of the patients used these therapies upon the recommendation of family members, friends, or other patients did not report the use of CAM to the doctor or nurse (7).

In studies with 156 patients diagnosed with gynecologic cancer in Turkey, $40 \%$ of the patients said that they used CAM methods to strengthen the immune system, $25 \%$ of patients used them to fight cancer directly, $18 \%$ of the patients used them to prevent progress of the disease, and the majority of the patients used them to support the treatment. Although prayer with a ratio $94.7 \%$ is one of the most common approaches, the usage rates of herbal approaches were found to be quite high, differing between $28.2 \%$ and $95.2 \%$ from study to study (8). The most commonly used plants are Urtica dioica, $\mathrm{Ca}$ mellia sinensis, Aloe vera, Zingiber officinale, Vitis vinifera, and Linum usitatissimum (9).

The aim of this study is to determine the use of the plants and mushrooms as one of the CAM methods among cancer patients. Within this scope, a questionnaire survey was conducted with 100 cancer patients who are receiving treatment at polyclinics at the Istanbul University Institute of Oncology. It was determined how the patients obtained the plants and mushrooms, how the age, gender or socioeconomic status affect the plants and mushrooms used and what kind of feedback the patients give about their experience. 


\section{MATERIALS AND METHODS}

After the approval of the Ethics Committee (Istanbul University, Istanbul Faculty of Medicine, Clinical Research Ethics Committee) in March 2017, a survey was conducted with 100 patients receiving treatment at the polyclinics of the Istanbul University Institute of Oncology from March to May 2017. Questionnaires were administered verbally in a faceto-face interview with patients. The purpose of the questionnaire was explained to the patients, it was stated that they can skip questions if they didn't want to answer and they could finish the survey at any point. After receiving the approval of participation, questions (Table 1) were asked. The aim of the questionnaire was to establish a relationship between plant use and socio-economic status through questions about education, monthly income and marital status of the patients. The relationship between plant use and the status of cancer is intended to be established by asking questions regarding the type of cancer, stage, chemotherapy-radiotherapy status, and the presence of cancer diseases in the family. The questions that were asked to the patients included the names of the plants they used, which parts of these plants they used, the harms and benefits of the plants, from whom they heard about these plants, where they obtained them, how much money they spent, whether or not they recommended them, and whether they informed their medical staff or not. By this way, it

Table 1. Survey questions

\begin{tabular}{|l|l|}
\hline $\begin{array}{l}\text { Name-Surname } \\
\text { (optional) }\end{array}$ & $\begin{array}{l}\text { Which plants and mushrooms } \\
\text { do you use? }\end{array}$ \\
\hline Gender and Age & $\begin{array}{l}\text { Which parts of the plant do } \\
\text { you use? }\end{array}$ \\
\hline $\begin{array}{l}\text { Marital and educational } \\
\text { status }\end{array}$ & $\begin{array}{l}\text { How do you use the plants and } \\
\text { mushrooms? }\end{array}$ \\
\hline The monthly income & $\begin{array}{l}\text { Did you benefit or harm from } \\
\text { plants and mushrooms? }\end{array}$ \\
\hline $\begin{array}{l}\text { Do you have a history of } \\
\text { cancer in your family? }\end{array}$ & $\begin{array}{l}\text { Where or from whom did you } \\
\text { hear about these plants and } \\
\text { mushrooms? }\end{array}$ \\
\hline Cancer type & Where did you get it from? \\
\hline $\begin{array}{l}\text { Do you have chemothe- } \\
\text { rapy / radiotherapy? }\end{array}$ & $\begin{array}{l}\text { What is your reason for using } \\
\text { plants and mushrooms? }\end{array}$ \\
\hline $\begin{array}{l}\text { Do you use plants and } \\
\text { mushrooms for this } \\
\text { disease? }\end{array}$ & $\begin{array}{l}\text { Did you report the use to the } \\
\text { doctor? What was the reaction } \\
\text { of the doctor? }\end{array}$ \\
\hline
\end{tabular}

was aimed to find out the prevalence of plants used in Turkey and to compare the plants obtained in the literature survey with the plants used by the patients. The Microsoft ${ }^{\circledR}$ Excel version 16.37 software was used to evaluate the results of the questionnaires which were obtained in the survey. The data were analyzed by entering the program manually. According to the answers, the relationship between cancer patients' use of plants and their socio-economic status, the severeness of their disease and treatment was determined. According to the results of the survey, the plants and mushrooms used by the patients were identified and their anticancer mechanism of action, side effects and warnings were investigated.

\section{RESULTS}

100 cancer patients (51 male, 49 female) completed questionnaires at the Istanbul University Institute of Oncology between March and May 2017. The rate of using CAM methods as herbal treatment was found to be $24 \%$ (Figure 1). Curcuma longa was the most commonly used plant among these patients.

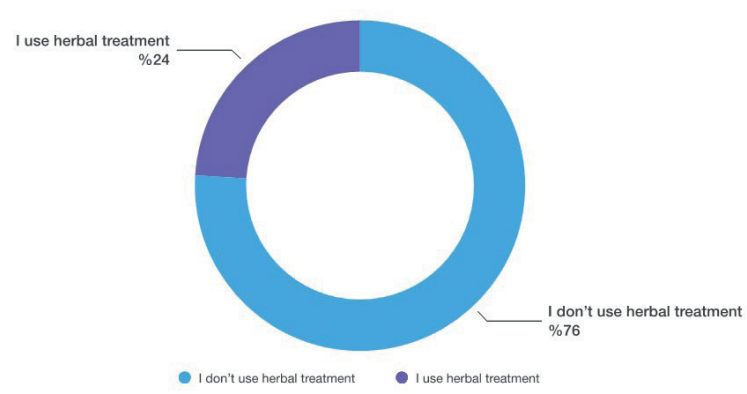

Figure 1. The rate of using CAM methods as herbal treatment in cancer patients

While 7 of the respondents said that they used Curcuma longa, 6 of them used Urtica dioica, 4 of them used Ganoderma lucidum, 4 of them used Camellia sinensis, 3 of them used Brassica oleracea, 3 of them used Zingiber officinale, 3 of them used Nigella sativa, and 2 of them used Matricaria chamomilla. (Figure 2).

Vitis vinifera, Cynara scolymus, Hypericum perforatum, Rosa canina, Dittrichia viscosa, Momordi- 


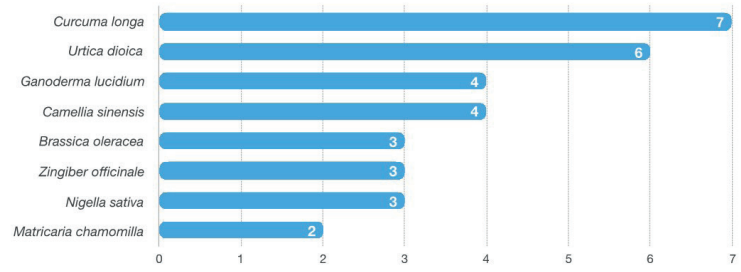

Figure 2. According to the survey results, the most used plants among cancer patients

ca charantia, Rheum palmatum, Anethum graveolens, Cinnamomum cassia and Silybum marianum were used by one of the participants. Plants are used alone or in combination with each other.

The anticancer efficacy of plants and mushrooms used by cancer patients has been confirmed by literature review. The anticancer mechanism of action, side effects and warnings of 17 plants and one mushroom used by cancer patients are given in Table 2 .

Three of the participants were diagnosed with breast cancer, 3 of them with prostate cancer, 3 of them with lymphoma, 2 of them with melanoma, 2 of them with kidney cancer, and one person was diagnosed with each of the following diseases: lung cancer, soft tissue cancer, pancreatic cancer, bone marrow cancer, nasopharynx cancer, cholangiocellular cancer, brain cancer. Prostate and breast cancer patients have been found to use more plants and mushrooms. No relationship was found between plants and mushrooms use and cancer type in this survey study.

Education level of the participants who use plants was as follows: $4.1 \%$ (1 patient) of them was illiterate and for the rest the highest degree obtained was as follows: $16.7 \%$ (4 patients) primary school, 58.3\% (14 patients) middle school, $20.8 \%$ (5 patients) high school or higher degree. A positive correlation between education level and plant use was found. Herbal treatment was used by these patients particularly to reduce the side effects of treatment and to treat the disease.

Among participants who use plants, 10 of them were female and 14 of them were male. The monthly income of $25 \%$ of the participants (6 patients) was less than $1,000 \mathrm{TL}, 66.7 \%$ of them (16 patients) were between $1,000-3,000 \mathrm{TL}, 8.3 \%$ of them (2 patients) were more than 3,000 TL. Therefore, it can be said that the herbal treatment is preferred more by people with a middle income.

The distribution of age among patients who use plants was as follows: $12.5 \%$ of them (3 patients) were 29 years-old or younger, $16.7 \%$ of them (4 patients) were between $30-45$ years-old, $58.3 \%$ of them (14 patients) were between 46-64 years-old, $12.5 \%$ of them (3 patients) were 65 years-old or older. The mean age of the patients who use plants and mushrooms was high due to the high average age of the patients.

The $8.3 \%$ of participants ( 2 patients) who use plants were widows, $25 \%$ of them (6 patients) were single and $66.7 \%$ of them (16 patients) were married. Demographic and clinical attributes of the patients who use plants or mushrooms for their cancer treatment are given in Table 3.

While $79.2 \%$ (19 patients) of the respondents stated that they benefited from herbal treatment, $20.8 \%$ (5 patients) stated that they did not see any benefit or harm. No serious adverse effects were reported by respondents. The most common sources of information about herbal treatment among cancer patients were friends / relatives $50.0 \%$ (11 patients), and media / internet $40.9 \%$ (9 patients). While 52.4\% (11 patients) of the respondents said that they obtained the plants from herbalists, $23.8 \%$ (5 patients) of them were provided by friends, $19 \%$ (4 patients) of them were provided from nature, no one obtained them from a pharmacy. The patients stated the reasons for using plants and mushrooms as follows; $66.7 \%$ (10 patients) used them to support treatment, $13.3 \%$ (2 patients) used them to reduce the side effects of medications and $20 \%$ ( 3 patients) used them to relax. $58.8 \%$ (10 patients) of the patients reported that the doctor didn't know about the plants they used. Characteristics of the plants and mushrooms used by patients are shown in Table 4.

Overall, it was observed that the use of herbal products increase with being married, being in the middle or older age group, having middle or upper-income level, having a high level of education and being diagnosed with particular types of cancer, namely, prostate and breast cancer. 
Table 2. The anticancer mechanism of action, side effects and warnings of 17 plants and one mushroom used by cancer patients

\begin{tabular}{|c|c|c|}
\hline Scientific name / Turkish name & $\begin{array}{l}\text { The anticancer mechanism of } \\
\text { action }\end{array}$ & Side effects / Warnings \\
\hline Curcuma longa L. / Zerdeçal & Anticancer (10). & $\begin{array}{l}\text { Gastric irritation, stomach upset, nausea, diarrhea, } \\
\text { allergic skin reactions, antithrombotic effects may } \\
\text { be seen (11). Curcumin could reduce the effect } \\
\text { of immunosuppressants. Turmeric could intera- } \\
\text { ct with non-steroidal anti-inflammatory drugs, } \\
\text { antiplatelet agents, antihyperlipidemic drugs and } \\
\text { warfarin (12). }\end{array}$ \\
\hline Urtica dioica L. /Isirgan & $\begin{array}{l}\text { Cytotoxic and apoptosis inducing } \\
\text { effects (13). }\end{array}$ & $\begin{array}{l}\text { Gastrointestinal adverse effects, allergic reactions, } \\
\text { pruritus, decreased urine volume, edema (14). The } \\
\text { use of } U \text {. dioica is contraindicated in people who } \\
\text { have reduced cardiac and renal function due to } \\
\text { fluid retention (15). }\end{array}$ \\
\hline $\begin{array}{l}\text { Ganoderma lucidum (Curtis) } \\
\text { P.Karst. / Reishi Mantarı }\end{array}$ & Anticancer (16). & $\begin{array}{l}\text { Because Ganoderma lucidum inhibits platelet } \\
\text { aggregation, it may have a synergistic effect with } \\
\text { blood thinners such as Aspirin and Warfarin. } \\
\text { Patients taking immunosuppressive drugs should } \\
\text { be careful (17). }\end{array}$ \\
\hline $\begin{array}{l}\text { Camellia sinensis (L.) Kuntze / } \\
\text { Yeşil Çay }\end{array}$ & Apoptosis (18). & $\begin{array}{l}\text { Insomnia, nervousness, nausea, rash, } \\
\text { gastrointestinal problems (19). Patients with hy- } \\
\text { pertension, severe liver disease, cardiac arrhyth- } \\
\text { mias, psychiatric disorders, insomnia should avoid } \\
\text { using the plant (20). }\end{array}$ \\
\hline Brassica oleracea L. / Brokoli & $\begin{array}{l}\text { Antioxidant, enzyme regulator, } \\
\text { apoptosis and cell cycle regulatory } \\
\text { effect (21). }\end{array}$ & $\begin{array}{l}\text { The plant should not be used for a long time in } \\
\text { diseases related to liver and thyroid (22). }\end{array}$ \\
\hline $\begin{array}{l}\text { Zingiber officinale Roscoe / } \\
\text { Zencefil }\end{array}$ & Anticancer activity (23). & $\begin{array}{l}\text { Allergic rashes, heartburn, palpitations, gas, nau- } \\
\text { sea, diarrhea, mouth irritation, bleeding, uterine } \\
\text { contraction (24). It has been recommended that } \\
\text { ginger supplements should be avoided in cases of } \\
\text { gallstones due to stimulating the secretion of bile } \\
\text { (25). }\end{array}$ \\
\hline Nigella sativa L. / Çörek Otu & $\begin{array}{l}\text { Antioxidant, anticancer and anti- } \\
\text { mutagenic effects }(26) \text {. }\end{array}$ & $\begin{array}{l}\text { Allergic contact dermatitis, gastrointestinal adver- } \\
\text { se effects (27). It may interact with immunosupp- } \\
\text { ressive or immunostimulant drugs (28). }\end{array}$ \\
\hline $\begin{array}{l}\text { Matricaria chamomilla L. / } \\
\text { Papatya }\end{array}$ & $\begin{array}{l}\text { Anticancer, apoptosis of tumour } \\
\text { cells (29). }\end{array}$ & Allergic reactivity $(30)$ \\
\hline Vitis vinifera L. / Üzüm & $\begin{array}{l}\text { Inhibited aromatase activity and } \\
\text { expression (31). }\end{array}$ & $\begin{array}{l}\text { Gastrointestinal disturbances, nausea, indigestion } \\
(20) \text {. }\end{array}$ \\
\hline Cynara scolymus L. / Enginar & $\begin{array}{l}\text { Antioxidant, anti-apoptotic effects } \\
(32) \text {. }\end{array}$ & $\begin{array}{l}\text { Allergic reactions, gastrointestinal disorders, } \\
\text { edema (33). }\end{array}$ \\
\hline $\begin{array}{l}\text { Hypericum perforatum L. / Sar1 } \\
\text { Kantaron }\end{array}$ & $\begin{array}{l}\text { Apoptosis of tumour cells and } \\
\text { inhibit angiogenesis (34). }\end{array}$ & $\begin{array}{l}\text { Agitation, gastrointestinal symptoms, photosensi- } \\
\text { tivity, skin conditions (35). }\end{array}$ \\
\hline Rosa canina L. / Kușburnu & Antiproliferative activity (36). & Rash, gastrointestinal complaints (37). \\
\hline $\begin{array}{l}\text { Dittrichia viscosa (L.) Greuter / } \\
\text { Yapıșkan Andız Otu }\end{array}$ & Anticancer (38). & It has hypoglycemic effects (39). \\
\hline $\begin{array}{l}\text { Momordica charantia L. / Kudret } \\
\text { Nar1 }\end{array}$ & $\begin{array}{l}\text { Anticancer potency against cancer } \\
\text { cell lines }(40) .\end{array}$ & $\begin{array}{l}\text { Hypoglycaemia and convulsions in children, it } \\
\text { should not be administered to children or taken } \\
\text { during breastfeeding (41). }\end{array}$ \\
\hline Rheum palmatum L. / Işgı̀n & $\begin{array}{l}\text { Antiproliferative effect and anti-a- } \\
\text { poptotic effects (42). }\end{array}$ & $\begin{array}{l}\text { The plant is used with calcium; calcium oxalate } \\
\text { crystals can accumulate in the kidney and gallb- } \\
\text { ladder (43). }\end{array}$ \\
\hline $\begin{array}{l}\text { Anethum graveolens L. / Dere } \\
\text { Otu }\end{array}$ & Suppressed the proliferation (44). & No side effects reported. \\
\hline $\begin{array}{l}\text { Cinnamomum cassia (L.) J.Presl } \\
\text { / Tarçın }\end{array}$ & $\begin{array}{l}\text { It inhibited the expression of } \\
\text { pro-angiogenic factors and regula- } \\
\text { tors of tumour progression (45). }\end{array}$ & Allergic contact dermatitis, hypoglycemia (46). \\
\hline $\begin{array}{l}\text { Silybum marianum L. Gaertn. / } \\
\text { Meryemana Dikeni }\end{array}$ & $\begin{array}{l}\text { Antioxidant and hepatoprotective } \\
\text { effects (47). }\end{array}$ & $\begin{array}{l}\text { Nausea, stomachache, diarrhea, headache, allergic } \\
\text { reaction, indigestion (48). }\end{array}$ \\
\hline
\end{tabular}


Table 3. Demographic and clinical characteristics of the patients who use plants or mushrooms for their cancer treatment

\begin{tabular}{|c|c|c|c|}
\hline \multirow{2}{*}{ Gender } & Male & 14 & $58.3 \%$ \\
\hline & Female & 10 & $41.7 \%$ \\
\hline \multirow{3}{*}{ Marital status } & Married & 16 & $66.7 \%$ \\
\hline & Single & 6 & $25 \%$ \\
\hline & Widow & 2 & $8.3 \%$ \\
\hline \multirow{4}{*}{$\begin{array}{l}\text { Age } \\
\text { Group }\end{array}$} & 29 and under & 3 & $12.5 \%$ \\
\hline & $30-45$ & 4 & $16.7 \%$ \\
\hline & $46-64$ & 14 & $58.3 \%$ \\
\hline & 65 and over & 3 & $12.5 \%$ \\
\hline \multirow{5}{*}{$\begin{array}{l}\text { Educational } \\
\text { status }\end{array}$} & Illiterate & 1 & $4.1 \%$ \\
\hline & Primary school & 4 & $16.7 \%$ \\
\hline & Middle school & 14 & $58.3 \%$ \\
\hline & High school & 2 & $8.3 \%$ \\
\hline & University & 3 & $12.5 \%$ \\
\hline \multirow{3}{*}{$\begin{array}{l}\text { The monthly } \\
\text { income }\end{array}$} & Less than $1000 €$ & 6 & $25.0 \%$ \\
\hline & Between 1000-3000£ & 16 & $66.7 \%$ \\
\hline & More than $3000 £$ & 2 & $8.3 \%$ \\
\hline \multirow{6}{*}{ Cancer Type } & Breast cancer & 3 & $12.5 \%$ \\
\hline & Prostate cancer & 3 & $12.5 \%$ \\
\hline & Lymphoma & 3 & $12.5 \%$ \\
\hline & Melanoma & 2 & $8.3 \%$ \\
\hline & Kidney cancer & 2 & $8.3 \%$ \\
\hline & Other & 11 & $45.8 \%$ \\
\hline
\end{tabular}

It was observed that there was no plant use in some of the polyclinics due to doctor's prohibition. Doctors do not recommend the use of plants to their patients or leave them to their own decisions due to reasons such as having side effects of plants, risk of drug interaction, not believing the effect of the plant, not being able to obtain correct information and information pollution. In addition, it was noticed that patients were timid in reporting the herbs they used to the healthcare professionals. All these situations are among the factors that limit this study.

\section{DISCUSSION}

The survey was conducted in order to determine the application of herbal use among cancer patients at the Istanbul University Institute of Oncology, one of the most important oncology clinics in Turkey.
Table 4. Characteristics of plants and mushrooms used by patients

\begin{tabular}{|c|c|c|c|}
\hline \multirow{3}{*}{ Benefit / Harm } & I saw benefit. & 19 & $79.2 \%$ \\
\hline & I saw harm. & 0 & $0.0 \%$ \\
\hline & $\begin{array}{l}\text { I saw neither benefit } \\
\text { nor harm. }\end{array}$ & 5 & $20.8 \%$ \\
\hline \multirow{5}{*}{$\begin{array}{l}\text { Information } \\
\text { source }\end{array}$} & Friends / Relatives & 11 & $50.0 \%$ \\
\hline & Media /Internet & 9 & $40.9 \%$ \\
\hline & Herbalist & 1 & $4.5 \%$ \\
\hline & Pharmacy & 0 & $0.0 \%$ \\
\hline & Books & 1 & $4.5 \%$ \\
\hline \multirow{5}{*}{ Supply } & $\begin{array}{l}\text { Collecting from } \\
\text { nature }\end{array}$ & 4 & $19.0 \%$ \\
\hline & Friends / Relatives & 5 & $23.8 \%$ \\
\hline & Herbalist & 11 & $52.4 \%$ \\
\hline & Pharmacy & 0 & $0.0 \%$ \\
\hline & Other & 1 & $4.8 \%$ \\
\hline \multirow{3}{*}{$\begin{array}{l}\text { The purpose of } \\
\text { using plants/ } \\
\text { mushrooms }\end{array}$} & Support the treatment & 10 & $66.7 \%$ \\
\hline & Reduce side effects & 2 & $13.3 \%$ \\
\hline & Relaxation & 3 & $20.0 \%$ \\
\hline \multirow{2}{*}{$\begin{array}{l}\text { Whether the } \\
\text { doctor knows } \\
\text { that the patient } \\
\text { uses plants and/ } \\
\text { or mushrooms. }\end{array}$} & Yes & 7 & $41.2 \%$ \\
\hline & No & 10 & $58.8 \%$ \\
\hline
\end{tabular}

The aims of this study were to find out how patients obtain plants, how the age, gender or socioeconomic status affect the plant use and what kind of feedback the patients give about their experience. The results showed that there is no statistically significant relationship between gender, socioeconomic status and plant use. Prostate and breast cancer patients have been found to use more plants. This might be due to the high incidence of the disease (49). No relationship was found between plant use and cancer type in this survey study. A positive correlation between the education level and plant use was found. This might be due to the higher ratio of access to the media and internet among more educated patients in comparison to less educated one. It can be said that herbal treatment is preferred more by middle-income people. The mean age of the patients who use plants and mushrooms was high due to the high average age of the patients. This situation can be explained by the increase in the incidence of cancer in advanced ages (50). 
Furthermore, the results of this study were compared to plants with proven efficacy in cancer treatment. As a result, it has been observed that the plants used by patients with cancer are compatible with the plants that are proven to be used in cancer treatment.

In general, the use of plants and mushrooms was less than expected. This may be because cancer patients do not provide information due to doctor prohibition because of the reasons such as the side effects of plants, the risk of drug interaction, and the disbelief of the effect of the plant.

\section{CONCLUSION}

It has been observed that patients especially use plants in cancer treatment because of the common belief that plants, and mushrooms are beneficial, and have no side effects. Insufficient audits and controls, negative effects of the media, the insufficient number of physicians trained in the use of plants and the application of the treatment with plants by unqualified people bring about many problems.

Our personal observations make us think that there are deficiencies in the transfer of information of the patient. Primarily we have to discuss for which reasons patients use these products. Due to the nature of cancer disease, patients are seeking alternative searches and follow the suggestions of unqualified people under the title "expert" and "reliable" in uncontrolled media and social media. Secondly, and the most influencing part of the treatment process is the strict approach of oncologists.

With this study, which was conducted at the Istanbul University Institute of Oncology, it is hoped to give an idea about the plant use among cancer patients in Turkey. With similar studies in the future, we hope that more information will be learned about the use of plants and mushrooms to cure the diseases of cancer while trained experts will provide recommendations for the patient.

Phytotherapy should be used as a complementary treatment in addition to standard medical treatment. Evidence-based information about the advantages, disadvantages, and limitations of herbal treatment should be provided by experts trained in this field for all cancer patients and patient-centered guidance should be provided. This approach requires a multidisciplinary practice.

Hakem Değerlendirmesi: Dış bağımsız.

Peer Review: Externally peer-reviewed.

Etik Komite Onayı: Bu çalışma için etik komite onayı alınmıştır.

Ethics Committee Approval: Ethics committee approval was received for this study.

Yazar Katkıları: Çalışma Konsepti/TasarımE.A.U., B.T., H.O.T., M.E.; Veri Toplama- B.T., H.O.T., M.E.; Veri Analizi/Yorumlama- B.T., H.O.T., M.E.; Yazı Taslağı- H.O.T., M.E.; İçeriğin Eleştirel İncelemesi-E.A.U.; Son Onay ve Sorumluluk- E.A.U., B.T., H.O.T., M.E.; Malzeme ve Teknik Destek- H.O.T., M.E.; Süpervizyon- E.A.U., B.T., H.O.T., M.E.

Author Contributions: Conception/Design of Study- E.A.U., B.T., H.O.T., M.E.; Data AcquisitionB.T., H.O.T., M.E.; Data Analysis/Interpretation- B.T., H.O.T., M.E.; Drafting Manuscript- H.O.T., M.E.; Critical Revision of Manuscript-E.A.U.; Final Approval and Accountability- E.A.U., B.T., H.O.T., M.E.; Technical or Material Support- H.O.T., M.E.; Supervision- E.A.U., B.T., H.O.T., M.E.

Çıkar Çatışması: Yazarlar çıkar çatışması beyan etmemişlerdir

Conflict of Interest: Authors declared no conflict of interest.

Finansal Destek: Yazarlar finansal destek beyan etmemişlerdir.

Financial Disclosure: Authors declared no financial support.

Acknowledgements: Thanks to Fatma Betül Aydın for her contributions.

Teşekkür: Katkılarından dolayı Fatma Betül Aydın’a teşekkür ederiz.

\section{REFERENCES/KAYNAKLAR}

1. Faydaoglu E, Sürücüoglu MS. History of the Use of Medical and Aromatic Plants and their Economic Importance Kastamonu Üniversitesi Orman Fakültesi Dergisi 2011;11(1): 52-67.

2. Riddle MJ. Dioscorides on pharmacy and medicine. Austin: University of Texas Press; 1985. 
3. EngelLW,StrausSE. Development of therapeutics: opportunities within complementary and alternative medicine. Nat Rev Drug Discov 2002;1(3):229-37.

4. Falzon CC, Balabanova A. Phytotherapy An Introduction to Herbal Medicine. Prim Care 2017;44(2):217-27.

5. Fürst R, Zündorf I. Evidence-based phytotherapy in Europe: Where do we stand? Planta Med. 2015:81(12-13):962-7.

6. Çetin O. The Use of Complementary and Alternative Medicine in Eskisehir. SosyoEkonomi 2007;6(6): 89-106. (article in Turkish with an abstract in English)

7. Kav S, Hanoglu Z, Algier L. Use of Complementary and Alternative Medicine by Cancer Patients in Turkey: A Literature Review. UHOD 2008;28(4):32-8.

8. Başgöl Ş, Aslan E. Complementary and Alternative Medicines In Gynecologic Cancers: The Evidence-Based Approach. YBÜ Sağllk Bilimleri Fakültesi Hemşirelik E-Dergisi 2014;2(3):51-62.

9. Yildırım Y, Tinar S, Yorgun S, Toz E, Kaya B, Sonmez S, et al. The use of complementary and alternative medicine (CAM) therapies by Turkish women with gynecological cancer. Eur J Gynaecol Oncol 2006;27(1):81-5.

10. Shukla M, Jaiswal S, Sharma A, Srivastava PK, Arya A, Dwivedi AK, et al. A combination of complexation and self-nanoemulsifying drug delivery system for enhancing oral bioavailability and anticancer efficacy of curcumin. Drug Dev Ind Pharm 2016;43(5):847-61.

11. Nagpal M, Sood S. Role of curcumin in systemic and oral health: An overview. J Nat Sci Biol Med 2013;4(1):3-7.

12. Fetrow CW, Avila JR, editors. Professional's handbook of complementary and alternative medicine. Springhouse, PA: Springhouse; 1999.

13. Mohammadi A, Mansoori B, Aghapour M, Baradaran B. Urtica dioica dichloromethane extract induce apoptosis from intrinsic pathway on human prostate cancer cells (PC3). Cell Mol Biol 2016;62(3):78-83.
14. Chrubasik JE, Roufogalis BD, Wagner $\mathrm{H}$, Chrubasik SA. A comprehensive review on nettle effect and efficacy profiles, Part I: Herba urticae. Phytomedicine 2007;14(6):423-35.

15. World Health Organization. WHO Monographs on Selected Medicinal Plants Volume 2, World Health Organization. Geneva: World Health Organization; 2002.

16. Ameri A. Ganoderic Acid in the Treatment of Prostate Cancer. Jundishapur J Nat Pharm Prod 2012;7(3):85-6.

17. Wasser SP. Reishi or Ling Zhi (Ganoderma lucidum). Encyclopedia of Dietary Supplements 2005; 1:603-2

18. Suganuma M, Saha A, Fujiki H. New cancer treatment strategy using combination of green tea catechins and anticancer drugs. Cancer Sci 2011;102(2):317-23.

19. Schönthal AH. Adverse effects of concentrated green tea extracts. Mol Nutr Food Res 2011;55(6):874-85.

20. Braun L, Cohen M, editors. Herbs and Natural Supplements Volume 2: An Evidence-Based Guide. Australia: Elsevier Health Sciences; 2015.

21. Vasanthi HR, Mukherjee S, Das DK. Potential health benefits of broccolichemico-biological overview. Mini-Rev Med Chem 2009;9(6):749-59.

22. Kruger CL. Generally Recognized As Safe (Gras) otification for the Use of Aqueous Broccoli Seed Extract Powder in Food. U.S. Food Drug Administration. Office of Food Additive Safety: 2013 July. Report No: 496.

23. El-Ashmawy NE, Khedr NF, El-Bahrawy HA, Abo Mansour HE. Ginger extract adjuvant to doxorubicin in mammary carcinoma: study of some molecular mechanisms. Eur J Nutr 2018;57(3):981-89.

24. Altman RD, Marcussen KC. Effects of a Ginger Extract on Knee Pain in Patients with Osteoarthritis. Arthritis Rheum 2001;44(11):2531-8.

25. Blumenthal M, Busse WR, Goldberg A, Gruenwald J, Hall T, Riggins W, Rister RS, editors. German Commission E Monographs: Therapeutic Monographs on Medicinal Plants. 
Austin, Texas: American Botanical Council; 1998.p.135-136.

26. Bourgou S, Bellila A, Falleh H, Ksouri R, Marzouk B. Phenolic composition and biological activities of Tunisian Nigella sativa L. shoots and roots. C R Biol 2008;331(1):48-55.

27. Ali BH, Blunden G. Pharmacological and toxicological properties of Nigella sativa. Phytother Res 2003;17(4):299-305.

28. El-Obeid A, Al-Harbi S, Al-Jomah N, Hassib A. Herbal melanin modulates tumor necrosis factor alpha (TNF-alpha), interleukin 6 (IL-6) and vascular endothelial growth factor (VEGF) production. Phytomedicine 2006;13(5):324-33.

29. Sung B, Chung HY, Kim N. Role of Apigenin in Cancer Prevention via the Induction of Apoptosis and Autophagy. J Cancer Prev 2016;21(4):216-26.

30. Andres C, Chen WC, Darsow U, Mempel M, Ollert M, Ring J. Anaphylactic Reaction to Camomile Tea. Allergol Int 2009;58(1):135-6.

31. Kijima I, Phung S, Hur G, Kwok SL, Chen S. Grape seed extract is an aromatase inhibitor and a suppressor of aromatase expression. Cancer Res 2006;66(11):5960-7.

32. Miccadei S, Di venere D, Cardinali A, Romano F, Durazzo A, Foddai MS, et al. Antioxidative and apoptotic properties polyphenolic extracts from edible part of artichoke (Cynara scolymus L.) on cultured rat hepatocytes and on human hepatoma cells. Nutr Cancer 2008;60(2):276-83.

33. Englisch W, Beckers C, Unkauf M, Ruepp M, Zinserling V. Efficacy of Artichoke dry extract in patients with hyperlipoproteinemia. Arzneimittelforschung 2000;50(3):260-5.

34. Lorusso G, Vannini N, Sogno I, Generoso L, Garbisa S, Noonan DM, et al. Mechanisms of Hyperforin as an anti-angiogenic angioprevention agent. Eur J Cancer 2009;45(8):1474-84.

35. Linde K, Knuppel L. Large-scale observational studies of hypericum extracts in patients with depressive disorders: a systematic review. Phytomedicine 2005;12(1-2):148-57.
36. Jiménez S, Gascon S, Luquin A, Laguna $M$, Ancin-Azpilicueta C, Rodriguez-Yoldi MJ. Rosa canina extracts have antiproliferative and antioxidant effects on caco-2 human colon cancer. PloS one 2016;11(7):e0159136.

37. Chrubasik E, Rougofalis BD, Müller-Ladner U, Chrubasik S. Systematic review on the Rosa canina effect and efficacy profiles. Phytother Res 2008;22(6):725-33.

38. Merghoub N, Btaouri H, Benbacer L, Gmouh S, Trentesaux C, Brassart B, et al. Inula Viscosa Extracts Induces Telomere Shortening and Apoptosis in Cancer Cells and Overcome Drug Resistance. Nutr Cancer 2016;68(1):131-43.

39. Zeggwagh NA, Quahidi ML, Lemhadri A, Eddouks M. Study of hypoglycaemic and hypolipidemic effects of Inula viscosa L. aqueous extract in normal and diabetic rats. J Ethnopharmacol 2006;108(2):223-7.

40. Güneş H, Alper M, Çelikoğlu N. Anticancer effect of the fruit and seed extracts of Momordica charantia L. (Cucurbitaceae) on human cancer cell lines. Trop J Pharm Res 2019;18(10):2057-65.

41. Basch E, Gabardi S, Ulbricht C. Bitter melon (Momordica charantia): a review of efficacy and safety. Am J Health-Syst Pharm 2003;60(4):356-9.

42. Sui JQ, Xie KP, Zou W, Xie MJ. Emodin inhibits breast cancer cell proliferation through the ERaMAPK/ Akt-cyclin D1/Bcl2 signaling pathway. Asian Pac J Cancer Prev 2014;15(15):6247-51.

43. Malik MA, Bhat SA, Fatima B, Ahmad SB, Sidiqui S, Shrivastava P. Rheum emodi as valuable medicinal plant. IJGMP 2016;5(4):35-44.

44. Mohammed FA, Elkady AI, Syed FQ, Mirza MB, Hakeem KR, Alkarim S. Anethum graveolens (dill) - A medicinal herb induces apoptosis and cell cycle arrest in HepG2 cell line. J Ethnopharmacol 2018;219:15-22.

45. Kwon HK, Jeon WK, Hwang JS, Lee GG, So JS, Park JS, et al. Cinnamon extract suppresses tumor progression by modulating angiogenesis and the effector function of CD8+ T cells. Cancer Lett 2009;278(2):174-82.

46. Chevallier A. Encyclopedia of Herbal Medicine: 550 Herbs and Remedies for Common Ailments. 
Third ed. Dorling New York, USA: Kindersley Book; 2016.

47. Zhu XX, Ding YH, Wu Y, Qian LY, Zou H, He Q. Silibinin: a potential old drug for cancer therapy. Expert Rev Clin Pharmacol 2016;9(10):1323-30.

48. El-Kamary SS, Shardell MD, Adel-Hamid M, Ismail S, El-Ateek M, Metwally M, et al. A randomized controlled trial to assess the safety and efficacy of silymarin on symptoms, signs and biomarkers of acute hepatitis. Phytomedicine 2009;16(5):391-400.

49. Stewart BW, Wild CP. World Cancer Report. Lyon: IARC; 2014.

50. NCI (National Cancer Institute) Age and Cancer Risk. serial online 2015 April (cited 2020 April 20) Available from: https://www.cancer.gov/ about-cancer/causes-prevention/risk/age 